\title{
NEW LIGHT THROUGH OLD WINDOWS: A NEW PERSPECTIVE ON THE BRITISH ECONOMY
} IN THE SECOND WORLD WAR

Dr. W.P. Howlett

Number: 2/92

April 1992 

Working Paper No. 2/92

\title{
New Light Through Old Windows: A New Perspective on the British Economy in the Second World War
}

\author{
W.P. Howlett
}

(c)W.P. Howlett,

April 1992

Economic History Department,

London School of Economics. 
W. Peter Howlett

Department of Economic History

London School of Economics

Houghton Street

London WC2A 2AE

United Kingdom

Phone: $\quad+44(0) 719557081$

Fax: $\quad+44(0) 719557730$

Additional copies of this working paper are available at a cost of $£ 2.50$. Cheques should be made payable to 'Department of Economic History, LSE' and sent to the Departmental Secretary at the address above. 


\section{New Light Through Old Windows: A New Perspective On The}

\section{British Economy In The Second World War}

In the Second World War the normal market orientation of the British economy was replaced by a system of centralised control and economic planning. The key feature of this system was the process of physical planning operated by the central authorities through which they controlled the allocation and use of scarce resources such as labour, steel and capacity. In the official history volumes (which dominate the historiography), however, one central question evades the reader how were these scarce resources allocated?' Page after page in volume after volume offers descriptive evidence of the decisions taken about resource allocation but far too often there is no analysis of how this was actually managed. The reader is allowed to drown in a sea of information, rarely being told what were the real and potential problems faced in resource allocation, what moves were taken to overcome the inherent frictions, and whether or not those moves were successful.

I wish to contend that, given the institutional framework of the wartime administration, the central issue of the management of the British war economy was the potential and actual interdepartmental competition, its affect on resource allocation and the moves taken to counter it and promote cooperation. The strengths and weaknesses of the British wartime economy cannot be understood unless we know how resources were allocated and how the process of allocation evolved.

The distinguishing feature of any economic system is how it chooses to allocate resources. In a market economy allocation is achieved through the operation of

${ }^{1}$ The two most important volumes in this series are: W.K. Hancock and M.M. Gowing, British War Economy (London and Nendeln 1975) and M.M. Postan, British War Production (London and Nendeln 1975). 
the price mechanism. In Britain in the Second World War, however, the Churchill Government abandoned any pretence of a laissez-faire attitude and evolved a system for the central direction of the war economy. An attempt was made to manage the economy without using prices as a guideline. The major allocative decisions were reached not through the interplay of market forces but through the invisible, and not so invisible, hands of government bureaucracies. Central government expenditure on defence, for example, increased from $£ 254$ million in $1938 / 9$ to $£ 5,100$ million in $1944 / 5$ and this was matched by an expansion in the size of the non-industrial civil service staffs in the five war related government departments from 53,000 in 1939 to 241,000 in $1944 .^{2}$

Those government departments responsible for the armed forces and for supplying them with munitions came to dominate the economic system and they had priority with regards to scarce resources, such as steel and labour, within the economy. These resources were allocated by War Cabinet committees to which the departments made representations. All that stood between a department and the achievement of its desired allocation were the representations of other departments and thus the potential for departmental competition existed.

The allocation of resources to a department depended on the relative priority given by the War Cabinet to their production programme and the relative strength of that department compared to other departments, including the ability of each of the service departments (those directly responsible for the army, navy and air force, respectively the War Office, the Admiralty and the Air Ministry) to influence overall military strategy. In order to ensure that it did not lose out in the competition for scarce resources, a department had either to present a highly persuasive case to the central allocator or it had to find ways of demonstrating

${ }^{2}$ Central Statistical Office, The Statistical Digest of the War (London and Nendeln 1975), 31 and 195; government expenditure is expressed in nominal values. 
that the demands presented by other departments were weaker than its demands. Thus, resource allocation was the result of military necessity, productive possibilities and bureaucratic friction. In such a system the relationship between different departments and, more importantly, the relationship between each different department and the bodies responsible for resource allocation will become the focal point of the system - these relationships will define power, distribution and efficiency in the economy.

In section I a simple game theoretic device will be used to show the potential problems faced by the central authorities; section II then sets out a formalised model of how the wartime British economy actually operated in terms of the process of physical planning; section III looks at how mechanisms that promoted cooperation evolved; the final section argues that there is still much to learn about the wartime economy and that the new approach suggested in this paper is a useful way of analyzing many of the important issues - that it is possible to bring new light through old windows.

In a centrally managed or administered economy in which most of the important resources are distributed by the central authorities the role of the price mechanism as an efficient carrier and conveyor of information becomes redundant. Instead, efficiency is crucially dependent upon the availability and processing of statistical, strategic and other technical information. Thus, the success of the system is decided by the flow and stock of non-price information (such as the alloy steel capacity of the country or the number of workers required to produce one heavy bomber). 
In such a system, efficiency can only be ensured on two conditions: firstly, that all information is made available, at the minimum possible cost, to the apparatus that serves the central allocators; second, that the apparatus is an efficient information filtering service. The efficiency of the information filtering service will be defined by its ability to provide a comprehensive service, to coordinate its material and to render complex, quantitative issues meaningful through providing succinct reports to the decision-takers. These skills are important because if too little information is provided it is almost certain that a non-optimal decision will be made but, on the other hand, with too much information the path to the optimal outcome may become blurred in a thick fog of technical detail. If the bodies which decide on the nature of the different production and allocation programmes cannot evolve a cooperative strategy which ensures free and efficient information flows then it is likely that the system will be inefficient.

In order to show the tensions that could exist in such a system, and in particular to show the potential for departmental conflict, it is necessary to start with some simplifying assumptions (these will be relaxed later). It will initially be assumed that the information filtering process is in fact efficient and that the more information that is available the more efficient will be the system. In a wartime economy it is possible to add two motivational assumptions to this: first, everyone in the system has a common interest in maximising the output of the economy and therefore in achieving the most efficient allocation of resources in relation to the strategic needs (that is, they desire to win the war); second, each supply department has a strong belief in the importance of its own particular work (that is, it believes that the war can only be won if it maximises its output within the set strategic considerations). ${ }^{3}$

${ }^{3}$ Here the path pioneered by W.A. Niskanen, Bureaucracy and Representative Government (Chicago and New York 1971), is followed in that it is implicitly assumed that the bureaucrat has a utility function which she attempts to maximise. This utility function is strongly linked to the size of the departmental budget and 


\section{Figure 1. Departmental Dilemma}

\begin{tabular}{ccc} 
& \multicolumn{2}{c}{ DEPARTMENT X } \\
& ALL & SELECTIVE \\
ALL & a & b
\end{tabular}

DEPARTMENT

$\mathrm{Y}$

SELECTIVE

c

d

We can now run through a simple abstract game to see what were the potential problems of such a system. Imagine that there are two departments (X and $\mathrm{Y}$ ) competing for a particular resource. Each department has two options: it can reveal all the information it has available to the central allocator or it can choose to provide the central allocator with selective information (this would be designed to strengthen its case for the resource or, alternatively, not to weaken it). The dilemma faced by each department is illustrated in figure one which shows the four possible strategies that could be adopted. In a system in which only the first motivational assumption is applicable then the outcome would be a (both departments would reveal all the relevant information at their disposal to the central allocator), as there would be no reason to withhold information. This would be the best solution for the economy as a whole; $\mathbf{a}$ is the optimal outcome. However, if both assumptions hold then the outcome will not be optimal. It is unlikely to be $\mathbf{b}$ or $\mathbf{c}$ either because the department that is selective, assuming that its selection does indeed make its case more favourable, will, usually, be in a stronger position than the department that is not selective. Thus, the most likely outcome, indeed the only outcome in a system where both motivational

hence the bureaucrat is no longer a neutral agent in the decision-making process. 
assumptions hold and all departments are rational, is $\mathbf{d}$. With outcome $\mathbf{d}$ it is indeterminate which department will be in a stronger position to receive the resources it wants because this will depend on how each selects and presents its material for the central allocator. What is apparent, though, is that for the economy as a whole $\mathbf{d}$ is the worst possible result because it provides the central allocator with the least amount of information.

An explicit example of the fact that government departments in Britain in the Second World War were forced to follow selective information policies was given by Devons in his discussion of the Monthly Statistical Bulletin of the Ministry of Aircraft Production. ${ }^{4}$ The Bulletin was a comprehensive statistical work produced by the Ministry and originally circulated freely to all who wanted it. The Ministry soon discovered, however, that in interdepartmental disputes the Bulletin was a liability. By manipulating the statistics contained in it rival departments could demonstrate weaknesses in the Ministry's case as opposed to their case. Further, because the rival departments did not produce a similar document the Ministry could not retaliate in a like manner. A review of the role of the Bulletin resulted in a decision to curtail its internal circulation and to circulate only a censored version to outside agencies (that is, to select and circulate only that information deemed harmless by the department). There is also ample evidence of explicit departmental conflict in the wartime economy: for example, there were fierce disputes between various departments over the allocation of drop forgings in 1941; and, the Ministry of Aircraft Production and the Admiralty had several confrontations over such things as the production of Hispano-Suiza and Oerlikon Guns in 1941 and the level of production of Barracuda aircraft in 1943.

${ }^{4}$ E. Devons, Planning in Practice (Cambridge 1950), 152-4.

${ }^{5}$ Public Records Office, Kew (PRO)/BT28/104, RM16(Part II), meeting of the sub-committee on drop forgings, 1-3, 9 July 1941; PRO/CAB92/2, meeting of the Defence Committee (Operations), 27 March and 29 April; PRO/CAB92/54, meeting of the Production Executive, 4-5, 31 March 1941; PRO/CAB70/6, 
The 'game' presented above did not reflect what actually occurred in the resource allocation process in wartime Britain - it is an abstract core model to which certain modifications can be made. Three points can be briefly mentioned. First, it should be realised that what has been presented up to now has been a static and passive procedure. In the wartime economy the allocation process was, however, both dynamic and interactive. The central allocator could, and did challenge the figures presented by the departments to support their case. Indeed, the ability of the central allocators (and their technical advisers) to transform a departmental programme into its necessary resource requirements with a good degree of accuracy improved over time.

The effect of this can again be demonstrated by looking at the Ministry of Aircraft Production. In the early years of the war the Ministry operated the so-called 'carrot' production programmes whereby they deliberately inflated the programme above what they thought could be achieved by as much as $15 \% .^{6}$ The central allocators noticed that the Ministry continually had difficulty meeting its targets and that therefore its resource demands seemed to be out of step with what was actually produced. Pressure from the central allocators was one of the reasons why, in 1943, the Ministry adopted the so-called Realistic Programme. ${ }^{7}$ This pressure also caused it to develop its own highly sophisticated statistical body to outflank the central statisticians.

meetings of the Defence Committee (Supply), 7 January and 30 March 1943.

${ }^{6}$ Indeed, PRO/AIR20/1913, for example, contains several tables in which Ministry of Aircraft Production officials had calculated figures equal to 85 per cent of the official programme which were then used internally to judge production performance, even though externally they bid for resources on the basis of the full programme.

${ }^{7}$ See the correspondence between Llewellin (then Minister of Aircraft Production) and Sinclair (the Secretary of State for Air) in early October 1942 in PRO/AVIA9/9. 
The second modification of the Departmental Dilemma game relates to the fact that it is not necessarily true that the goal of the central allocators was to achieve the most efficient outcome possible. Indeed, reading the minutes of the various War Cabinet committees it soon becomes obvious that the central allocators were more interested in arriving at the 'best possible compromise' situation. They realised that to achieve the most efficient outcome required an amount of time and a degree of statistical, production and strategic knowledge which was simply not available to them.

Finally, the game as outlined above is based on rules of conflict, ignoring the role of cooperation. In practice, however, cooperation was especially important at what can be called the micro-level of relations between departments and committees. At this level officials were able to develop informal contacts which facilitated a freer movement of information. Thus, even where departmental heads were in conflict, information flows occurred at the micro-level and so enabled the system to achieve outcomes that were more efficient than it would otherwise have been possible to achieve.

\section{II}

To examine the operation of the economy in this period, to evaluate the process of allocating scarce resources, it is therefore necessary to understand the organisation of the central bureaucracy and in particular to understand the interaction and relationship between different departments and between departments and the central allocating bodies. Figure two shows the organisational structure of the British wartime economy, from May 1940, focusing on the information flows which were important to the central decision-making process as it affected resource allocation and war production. 
Figure two is, of necessity, an abstraction; in particular, it is a static representation and does not attempt to capture all the organisational changes that occurred during the war. It does, however, capture the essence of how the system operated during most of the period. In addition to showing the main bodies, it also indicates some of their more important members. The links shown in figure two are not exhaustive - they merely represent the main channel of decision-making with regards to war production. In reality there were links between most of the different components shown, in particular there were strong links between the service departments and their sister supply departments (the Ministry of Aircraft Production, the Ministry of Supply and the production arm of the Admiralty).

The decision-making process was split into two spheres: the Production Sphere and the Strategic Sphere (I am primarily interested in the munitions programmes and have therefore ignored the civilian economy; however, it would be fairly easy to take this sector into account by simply adding a third, civilian, sphere). In the Strategic Sphere the military decisions which affected production were taken; in the Production Sphere, the production programmes were formulated and implemented so as to meet the military needs. There were three stages to the decision-making process: first, the strategic priorities were decided upon; these were then converted into Control Figures (representing the munitions programmes); finally, the Correction Principle modified the Control Figures in the light of events not apparent when they were set. ${ }^{8}$

${ }^{8}$ For a fuller discussion of some of the theoretical issues raised by this approach see W.P. Howlett, 'Towards a Model of the Central Decision-Making Process in a War Economy', Discussion Paper in Economics, 89/7 (July 1989), Department of Economics, University of Stirling. This draws on J. Kornai, Antiequilibrium, (Amsterdam, 1971) and D. Granick, 'An Organisational Model of Soviet Industrial Planning', Joumal of Political Economy, 67 (1959), 109-32. 
Figure 2. An organisational model of the British economy in the Second World War

\begin{tabular}{|c|c|}
\hline \multicolumn{2}{|c|}{ WAR CABINET $(1,2,3,4,6,7,11)$} \\
\hline$\downarrow$ & $\uparrow$ \\
\hline $\begin{array}{l}\text { DEFENCE COMMITTEE } \\
\text { (SUPPLY) } \\
(1,3,4,5,7,9,10,11,12)\end{array}$ & $\begin{array}{c}\text { DEFENCE COMMITTEE } \\
\text { (OPERATIONS) } \\
(2,4,5,7,10,11,12)\end{array}$ \\
\hline$\downarrow$ & $\uparrow$ \\
\hline $\begin{array}{l}\text { PRODUCTION COMMITTEE } \\
\qquad(3,8,9)\end{array}$ & $\begin{array}{c}\text { CHIEFS-OF-STAFF } \\
\text { COMMITTEE } \\
(5,11)\end{array}$ \\
\hline$\downarrow$ & $\uparrow$ \\
\hline $\begin{array}{l}\text { SUPPLY DEPARTMENTS and } \\
\text { the } \\
\text { MINISTRY OF LABOUR }\end{array}$ & $\begin{array}{c}\text { SERVICE } \\
\text { DEPARTMENTS }\end{array}$ \\
\hline$\downarrow$ & $\uparrow$ \\
\hline INDIVIDUAL FIRMS & THEATRES OF WAR \\
\hline
\end{tabular}

PRODUCTION SPHERE

STRATEGIC SPHERE

\section{KEY}

1. Anderson

2. Attlee

3. Bevin

4. Churchill

5. Chiefs-of-Staff

6. Chancellor of the Exchequer
7. Minister of Production

8. President of the Board of Trade

9. Supply ministers

10. Service ministers

11. Bridges

12. Ismay

Service departments are the Admiralty, the Air Ministry and the War Office.

Supply departments are the Admiralty, the Ministry of Aircraft Production and the Ministry of Supply. 
Information from the theatres of war was gathered by each of the service departments and was used by them to develop their medium term strategic plan (in terms of the munitions they would require). Each department then presented its case at a meeting of the Chiefs-of-Staff Committee. ${ }^{9}$ This body met daily during the war to discuss the military situation but it rarely debated anything in depth - its purpose was to accept (and therefore refer to a higher authority), reject or return for consideration reports submitted to it by the Joint Planning bodies or individual Chiefs-of-Staff. ${ }^{10}$ The Committee referred any questions it had to the Joint Planning Staff. This was composed of the equivalent of a Director of Plans seconded from each of the three armed forces. In turn, the Staff would nominate an ad hoc Inter-Service Planning Staff, with appropriate outside help, to tackle a particular problem and report back to the Chiefs-of- Staff Committee. In this way the decisions of the armed forces and the information at their disposal could be channelled up to the highest levels. The decisions taken by the Chiefs-of-Staff Committee were passed to the Defence Committee (Operations). It ran a final eye over the plans before they were presented to the War Cabinet." The main function of the Defence Committee (Operations) would seem to have been to try and settle any outstanding differences of opinion between the armed forces which the Chiefs-of-Staff Committee had been unable

${ }^{9}$ See PRO/CAB79/5-32. 1942.

${ }^{10} \mathrm{PRO} / \mathrm{PREM} 3,119,6$, correspondence between Ismay and Churchill, March

${ }^{11}$ See PRO/CAB69/1-7. 
to resolve.

Since officially the only permanent member of the Defence Committee (Operations) was Churchill, it can be seen that he played a vital role in setting the strategic objectives, or what I term the Priorities. He exerted pressure on the principal departments and Cabinet committees through the Prime Minister's Personal Minutes. These could cover anything and everything. After the relatively listless Chamberlain administration these minutes injected a sense of urgency into the system and they 'did much to confirm the feeling that there was now a strong personal control at the centre' to which the Whitehall machinery responded immediately and radically. ${ }^{12}$ However, there was criticism that sometimes Churchill interfered in what were primarily departmental affairs and this caused particular irritation if it was felt that the hand of his personal adviser Cherwell was behind the minutes. ${ }^{13}$

The War Cabinet was responsible for the overall direction of the state. Its members represented the senior ministries of the Crown and as such they reflected the political balance of the Coalition Government. The supply and

${ }^{12}$ J. Wheeler-Bennett (ed.), Action This Day (London 1968), 20-22, 50-1, 150.

${ }^{13}$ According to one senior minister, Anderson was 'very concerned' about the way Churchill interfered with 'everybody's department ... without any regard to the history of the problem [and suggested solutions without] intimate knowledge of the difficulties ... below the surface' (S.M.M. Lawlor, 'British Politics and Strategy, May 1940-March 1941', Ph.D. dissertation, Ph.D. 11640, University of Cambridge (1984), 179). 
service ministers were excluded except in the case of Beaverbrook, whose place in the War Cabinet was not due to his ministerial brief but to his role as trusted adviser to Churchill. In most cases the War Cabinet merely rubber-stamped the decisions passed on to it by the coordinating committees. Thus, normally the Cabinet would receive the Priorities from the Defence Committee (Operations), note them and then pass them onto the Production Sphere. However, if there was any serious interdepartmental dispute, especially in the Production Sphere, which the coordinating bodies could not settle, the War Cabinet would act as the final arbitrator - as it had done in the First World War. ${ }^{14}$

As in the Strategic Sphere there were two levels of coordinating bodies in the Production Sphere - the Defence Committee (Supply) and the Production Committee. The main functions of the Defence Committee (Supply), like its strategic counter-part, appeared to have been to act as a buffer between its junior coordinating body and the War Cabinet, to run a check over the final production programmes presented to it by the Production Committee, and to sort out those disputes between the supply departments which the Committee was unable to resolve. ${ }^{15}$ Scott and Hughes aptly summed up the function of the Defence Committee (Supply) thus: '[it] dealt with ends rather than means, with figures

${ }^{14}$ J.A. Fairlie, British War Administration (New York 1919), 51; J. Turner, 'Cabinets, Committees and Secretariats: the Higher Direction of the War', in K. Burk (ed.), The War and the State (London 1982).

${ }^{15}$ See PRO/CAB70/1-7. 
rather than words, with decisions rather than discussion... [and was] the fountainhead of authority in production matters'. ${ }^{16}$

The means, words and discussions which the Defence Committee (Supply) did without were to be found in the Production Committee, whose main function was to try and coordinate the production programmes of the supply departments. The Production Committee used the Priorities (handed down from the War Cabinet) and information on the production possibilities to transform the strategic demands into tentative output and input requirements -the Control Figures. The Control Figures were then used by the central allocating bodies (which were normally subcommittees of the Production Committee, such as the Materials Committee and the Industrial Capacity Committee) to allocate resources between the various departments. The allocating committees were again staffed by members of the supply departments (and other interested agents) and as such they were nonneutral bodies - they were the focus of the Departmental Dilemma game. The Control Figures, in the form of production programmes and resource allocations, were handed down from the Production Committee to the supply departments who, in turn, placed orders with individual firms.

In terms of resource allocation, the principal body in the wartime economy was the Production Committee but there was no body with that title in the War ${ }^{16}{ }^{16}$ J.D. Scott and R. Hughes, The Administration of War Production
(London 1955), 410 . 
Cabinet organisation; this title has been used to encompass a series of bodies which broadly fulfilled the functions described above. The first body to fulfil the role of the Production Committee was the Ministerial Committee On Economic Policy. This was a Chamberlainite organ and was more concerned with financial economic problems (such as the balance of payments, prices, wages and taxation) than the physical economic problems (such as the availability and allocation of steel and labour) that were to determine the nature of the British war economy. ${ }^{17}$ This concern was reflected by the fact that the Chairman of the Committee was the Chancellor of the Exchequer. The decline of financial planning and the rise of physical planning was signalled by the creation, by Churchill, of the Production Council in May 1940, which effectively succeeded the Ministerial Committee on Economic Policy. This change in emphasis was reflected by the fact that the Chairman of the new body was the Minister Without Portfolio (Arthur Greenwood) and that its principal members were the Minister of Labour (Ernest Bevin), the supply ministers and, representing the civilian interests, the President of the Board of Trade. The Treasury was nowhere to be seen.

The Production Council experienced some teething problems and was replaced by the Production Executive in January 1941 and this latter body was itself abolished with the creation of the new Ministry of Production in 1942. One of the

${ }^{17}$ See PRO/CAB72/1-5. 
main reasons for the creation of the new ministerial post was the need to have a War Cabinet minister who had the authority to speak for all the supply and service departments in negotiations with the Americans. ${ }^{18}$ Within the Ministry of Production the successor to the Production Executive was, in many ways, the Joint War Production Planning Group and the Programme and Planning Division. The purpose of the Staff was: 'to see that sufficient weapons of the right kind were available at the right time....(and) to provide a link between strategy and production'; to ensure that all programmes were realistic and to adjust them as necessary in the light of strategic considerations and production possibilities; and, to coordinate the combined requirements of the three services in relation to each other. ${ }^{19}$ This new body went even further than the Production Executive as it was explicitly charged with trying to bridge the gap between the Strategic and Production Spheres, although the onus was still on trying to match production to strategy and not vice versa. ${ }^{20}$

If the War Cabinet and its committees were the engine of the wartime economy then the War Cabinet Office was its oil. The War Cabinet Office supplied the permanent civil servants to the War Cabinet and its committees. It reflected the organisational structure described above in that it was divided into a military (or

\footnotetext{
${ }^{18}$ Scott and Hughes, op. cit., 432-55.

${ }^{19}$ PRO/CAB92/39, JWPS(42)1, 30 March 1942.

${ }^{20}$ See PRO/CAB92/39-40.
} 
strategic) half and a civil (or production) half. The Permanent Secretary was Sir Edward Bridges and he was supported by a Deputy Secretary (Military) and a Deputy Secretary (Civil). They sat on all the senior directing bodies of the war economy and their subordinates sat on all other central committees. This meant that they were able to collate and coordinate information from the Production Sphere and the Strategic Sphere. The cooperation between the two halves of the War Cabinet Office was of fundamental importance in achieving a coherent policy between the various Cabinet committees they served. It gave a vertical and horizontal unity to the committees and to the departments and so ensured that the policies pursued were consistent across committees and across the Spheres. Without such a well structured and professional central secretariat the wartime economy would undoubtedly have been a more ad hoc and chaotic affair.

The final stage in the decision making process was what could be termed the Correction Principle. This represented the bargaining process which followed the issuing of the Control Figures to firms. Up to now we have described a basically static model in that all decisions have taken place in a single period where everything remains constant as the process works itself out. In reality, the process was a dynamic one and the administrative and production constraints facing the decision-makers were constantly changing. Thus, the original information on which the Priorities and the Control Figures were based might have become redundant by the time the final allocations were made - the strategic situation may 
have altered or new administrative or production bottlenecks may have occurred. The Correction Principle explicitly recognised the existence of such possibilities and allowed for a new round of bargaining to occur between firms and departments and between the departments and the Production Committee, to make adjustments to the programmes and the allocations. Typically such adjustments were marginal in nature.

One of the most important features of the war economy was the primary role of strategy. The flow of the decision-making process in figure two is shown to be from the theatres of war, through the Strategic Sphere to the War Cabinet and then down through the Production Sphere to the firms. This is merely stating the obvious - in times of war the essential thing is to win on the battlefield. Thus, the main determinant of the Control Figures is the strategic priorities: if strategic considerations demand that light tanks, bomber aircraft, and escort ships must be available to fight the enemy successfully then that is what the munitions industries must produce. The superiority of strategy over production could be seen by the fact that the decisions taken in the Strategic Sphere were self-contained in a way which those in the Production Sphere were not. The supply ministers were not represented on the coordinating committees in the Strategic Sphere (they could say nothing to influence strategic policy because they lacked the relevant information); the service ministers, on the other hand, were represented on the coordinating committees in the Production Sphere (they influenced production 
policy because it was geared, primarily, to meeting their requirements). Although the Production Sphere could affect strategy (for example, by failing to deliver a particular weapon at a particular time) it did not do so as an ex ante constraint.

\section{III}

The important role of information and knowledge can be gauged by the fact that relatively sophisticated information flows and information filtering systems were developed during the war. This can be illustrated by looking at the case of steel allocation. Most of the initial donkey work was done by the Iron and Steel Control. It collected information on the potential steel supply for the coming quarter and the steel requirements of the departments. ${ }^{21}$ The control was one of several material Controls run by the Raw Materials Department and it passed the information it had gathered to its superior. The Raw Materials Department then checked this information for balance and consistency before passing it on to the Materials Committee which was responsible for allocation. The Materials Committee was a sub-committee of the Production Committee and was composed of all the departments with an interest in the allocation of materials. In terms of steel allocation it was the most important body in the war economy - a fact that is not emphasised in the official histories. The Materials Committee used the detailed information at its disposal and the Control Figures as issued by the Production Committee to make the steel allocations for the coming quarter and

\footnotetext{
${ }^{21}$ See PRO/POWE5/114; PRO/POWE5/79-81.
} 
to sort out any departmental disputes. The Committee passed its recommendations (with a small information base) on to the Production Committee. Unless there had been an important development (or a serious interdepartmental dispute which the Materials Committee had been unable to settle), the Production Committee would simply ratify the recommendations of the Materials Committee. The allocations were then passed on to the War Cabinet, via the Defence Committee (Supply), for final approval (at each stage passing through another information filter).

At the top of the hierarchy, the authorities realised it was important that the many and varied information flows that occurred in the economy were coordinated properly and that there was independent advice available. Thus, they developed their own statistical and economic bodies and advisers; the most important of these were the Central Statistical Office, the Economic Section and the Prime Minister's Statistical Section, all of which utilised the abilities of academic economists and statisticians drafted into the system as temporary civil servants.

The Central Statistical Office and the Economic Section were vital parts of the Cabinet infrastructure. Given the importance of statistical information in the wartime economy it was vital that the War Cabinet could call on a neutral body to collect, collate and produce statistics. The Central Statistical Office was such 
a body: it was not allowed to make any comments on the statistics it produced other than technical comments. ${ }^{22}$ When there was a serious interdepartmental dispute its duty to provide "neutral" data which would allow the dispute to be settled.

Neutral economic advice was provided by the Economic Section which was staffed by some excellent academic economists, including John Jewkes, Lionel Robbins, Austin Robinson, James Meade, Alec Cairncross and Evan Durbin. The Section effectively acted as advisers to Sir John Anderson who was the de facto 'Prime Minister for the Economy' (Churchill being more interested in strategic matters). Their contribution made permanent civil servants (and ministers) realise that members of the ivory towers could play an important role in the economy, and their technical expertise was another foundation stone in the successful wartime organisation. $^{23}$

The Prime Minister's Statistical Section was a non-governmental body of specialists, headed by Professor Lindemann (who became Lord Cherwell in 1941), whose duty was to provide Churchill with independent criticisms and judgements

${ }^{22}$ Nuffield College Library, Oxford, Lord Cherwell's Papers (NC/LC), F86, 'English Statistical Experience Since the Outbreak of War', 14 July 1941.

${ }^{23}$ J.E. Meade, 'Obituary for Lionel Robbins', Economica, 52 (1985), 4; W.S. Churchill, The Second World War, Volume III: the Grand Alliance (London 1950), 76; Lord Chandos, The Memoirs of Lord Chandos (London 1962), 34; A. Cairncross and N. Watts, The Economic Section 1939-1961 (London and New York 1989). 
over a wide range of questions. They did this by constructing graphs, which were then bound into albums for easy inspection, to keep Churchill informed of the progress of events, and by offering advice on any proposals submitted to him. An important aspect of their work was the scrutiny of the requirements presented to the cental allocation bodies by the departments bidding for resources. It was their duty 'to winnow through the various figures in order to find instances where the requirement could be reduced to absurdity. ${ }^{24}$

This strong advocate role naturally aroused hostility in the departments being scrutinised as it was yet another layer of information filtering which many felt was unnecessary. Many civil servants, including some of those economists who worked as temporary civil servants, felt that although the Section could be constructive it was often destructive, causing them to run around for days examining ideas put into Churchill's head by the Section that they, the civil servants, knew from the beginning were not implementable. ${ }^{25}$

The Section probably also contributed to inefficiency in the central administration by duplicating work done by other bodies, particularly the Central Statistical Office. The two bodies had a close relationship and were in constant contact. In some ways this was inevitable as they were both concerned with similar areas,

${ }^{24}$ R.F. Harrod, The Prof. (London 1959), 201.

${ }^{25}$ I am indebted to conversations with Professor Sir Austin Robinson for these observations. 
although, unlike the Central Statistical Office, the Prime Minister's Statistical Section involved itself with data of an operational nature. ${ }^{26}$ It was also necessary in order to prevent too much overlap in their work. However, although the Central Statistical Office was primarily concerned with routine day-to-day statistical work and the Prime Minister's Statistical Section with more specific, specialised problems, there was undoubtedly much duplication of effort and work. ${ }^{27}$

The existence of information filtering systems such as existed for steel allocation and advisory bodies such as the Central Statistical Office, the Economic Section and the Prime Minister's Statistical Section ensured a freer and fuller flow of information occurred. In terms of the Departmental Dilemma game these bodies ensured that even if both departments wanted to follow selctive strategies the system as a whole would not end up in position d (with the least possible information released) since the departments would be harried by, for example, the Prime Minister's Statistical Section to release more information in order to justify their demands. Two other features of the wartime economy helped to reduce departmental conflict and to create an atmosphere of cooperation: the flexibility of the organisational structure and the development of informal contacts between

${ }^{26} \mathrm{NC} / \mathrm{LC} / \mathrm{F} 86$, op. cit..

${ }^{27}$ For more information on the Prime Minister's Statistical Section see the account given by G.D.A. MacDougall, 'The Prime Minister's Statistical Section', in D.N. Chester, Lessons of the British War Economy (London 1951), 58-68; and that given in Harrod, op. cit., 187-207. 
departments and between departments and the central allocators (in terms of figure one these features were encouraging a move towards postion a).

From figure two it can be seen that the organisational structure of the decisionmaking process was clearly defined, with a strict hierarchial nature. This was important because it meant that a decision taken at any level of the system could be communicated to all other levels quickly and effectively. In most cases there was also no dispute about the relative authority of any committee or other body in the system - where there were disputes they were normally settled quickly and the relationship between the disputers defined so as to avoid further conflict (although this is not to argue that administrative bottlenecks did not occur). However, flexibility was also built into the system by using ad hoc committees to deal with situations which the formal structure found difficult to accommodate. The best example of the importance of these informal mechanisms was a series of meetings (chaired by Anderson) on the manpower problem in 1942.

The demarcation lines with respect to labour questions were far from clear, in particular the Ministry Of Labour and the Ministry Of Production were disputing control over several areas. Such demarcation disputes were potentially wasteful of resources and the administrative friction they generated often led to duplication and hence inefficiency (in this case, it resulted in a situation where, at one point in 1942, three different bodies were working on almost identical assessments of 
future labour supply and allocation and using almost exactly the same data). The pivotal body in resolving the disputes and rescuing the labour budgets from organisational chaos was a series of ad hoc meetings under the chairmanship of Anderson, collectively known as the Lord President's Manpower Meetings. ${ }^{28}$ This ad hoc committee existed outside the formal organisational structure and it represented the most important labour committee in the crucial period of the Manpower Budgets, but in the official history volumes it is only alluded to in passing. The Lord President's Manpower Meetings brought together the heads of the Production Sphere and the Strategic Sphere and were advised by the most prominent non-executive officials in the economy. The breadth and depth of the membership of this unparalleled series of meetings allowed Anderson to present a coordinated view of the manpower situation across the economy and to develop a coherent manpower policy.

The development of informal contacts between officials was also crucial in overcoming the inevitable administrative friction of a wartime organisation by ensuring a freer flow of information. Devons, in talking of the relationship between the Air Ministry and the Ministry of Aircraft Production, emphasised the importance of informal contacts over time:

'Each department was unwilling to admit officials of the other to its secrets. Each feared that information so obtained might be used

${ }^{28}$ See PRO/LAB79/21-3. 
against it in interdepartmental argument, and wished to guard against premature action being taken by the other on schemes which were still under debate; however, as officials got to know each other the flow of information gathered pace, albeit unofficially. ${ }^{, 29}$

In other words, as time passed the unofficial links grew in strength; even though there were occasional squabbles at the Ministerial level, at lower levels the relations of the two departments improved progressively.

\section{IV}

There are two reasons why the conclusions of the official historians with regards to wartime resource allocation by Whitehall should be re-examined: firstly, there is the obvious fact that most of the volumes are now thirty or more years old; a stronger reason is that their analysis of the inherent economic relationships that underlay the process of wartime resource allocation tend to be rooted in anecdotal stories rather than in an objective framework. Given that the economic analysis of bureaucracy and central economic management has evolved much in the last two decades it is now possible to make the analysis of those underlying

${ }^{29}$ E. Devons, Papers on Planning and Economic Management (Manchester 1970), 54. 
economic relationships more explicit (as was attempted above with the Departmental Dilemma game) and to try and perceive the patterns that emerged and how the system evolved. By making the organisational structure more explicit many of the tensions and problems that existed in the system become clear, including: the role of military strategy in relation to production; the tendency towards departmental conflict and administrative friction; the central role of information flows; the need for flexibility within the formal central economic structure; and, the importance of the encouragement and development of informal links between officials in the system.

The system was never as rigid as figure two would suggest but in principle the central economic organisation changed surprisingly little during the war. Lessons had been learnt from the chaotic experiences of the First World War and in the decade prior to 1939 provisional plans had been drawn up which were then put into operation when war broke out. ${ }^{30}$ During the period of the Phoney War, however, the situation in Whitehall still had strong overtones of 'business as usual', as the Treasury chairmanship of the Ministerial Committee on Economic Policy demonstrated, and it took the German offensive in 1940 and the incoming Churchill administration to replace financial with physical planning.

Postan describes the Churchill years not in terms of a triumphal progress but as

${ }^{30}$ For a discussion of the inter-war preparations see Hancock and Gowing, op. cit., 45-72. 
a process of an economy learning to walk, often unsteadily and sometimes stumbling, on the new centrally managed terrain; ${ }^{31}$ and this was also reflected, or more probably was a reflection of, the evolution of the process of resource allocation itself. In 1940 and 1941 the learning experience was at its height and the problems of a centrally administered system that were outlined above were at their most virulent, the Ministry of Aircraft Production under Beaverbrook (May 1940 to May 1941) in particular ran amok, but gradually the growing knowledge of the central allocators and advisory bodies such as the Central Statistical Office and the Economic Section, the greater sophistication of information gathering and information filtering, and the growing understanding between officials engendered a spirit of cooperation that was the foundation of the successful running of the wartime economy.

${ }^{31}$ Postan, op. cit.. 


\section{$\underline{\text { References }}$}

\section{Primary Sources}

NC/LC: Nuffield College Library, Oxford. Lord Cherwell's Papers

PRO: Public Records Office, Kew, London

\section{Secondary Sources}

Cairncross, Alec and Watts, Nita. 1989. The Economic Section 1939-1961. London and New York.

Central Statistical Office. 1975. The statistical digest of the War. Revised edn. London and Nendeln.

Chandos, Lord. 1962. The memoirs of Lord Chandos. London.

Churchill, Winston. 1950. The Second World War, Volume III:the Grand Alliance. London.

Devons, Ely. 1950. Planning in practice. Cambridge.

Devons, Ely. 1970. Papers on planning and economic management. Edited by Alec Cairncross. Manchester.

Fairlie, J A. 1919. British war administration. New York.

Granick, David. 1959. "An Organisational Model of Soviet Industrial Planning", Journal of Political Economy, 67, 109-32.

Hancock, William K and Gowing, Margaret M. 1975. British war economy. Revised edn. London and Nendeln. 
Harrod, Roy F. 1959. The Prof.. London.

Howlett, W Peter. 1989. "Towards a model of the central decision-making process in a war economy", Discussion Paper in Economics, new series, 89/7 (July), Department of Economics, University of Stirling.

Kornai, Janos. 1971. Anti-equilibrium. Amsterdam.

Lawlor, S M M. 1984. "British politics and strategy, May 1940-March 1941". PhD diss., PhD 11640, University of Cambridge.

MacDougall, G D A. 1951. "The Prime Minister's Statistical Section". In DN Chester, Lessons of the British war economy, London, 58-68.

Meade, James E. 1985. "Obituary for Lionel Robbins", Economica, 52, 3-5.

Niskanen, W A. 1971. Bureaucracy and representative government. Chicago and New York.

Postan, M M. 1975. British war production. Revised edn. London and Nendeln.

Scott, J D and Hughes, R. 1955. The administration of war production. London.

Turner, J. 1982. "Cabinets, committees and secretariats: the higher direction of war". In Kathleen Burk, ed., The war and the state, London.

Wheeler-Bennett, John, ed. 1968. Action this day. London. 

